\title{
Isolation and characterization of microsatellite markers for the threatened African endemic tree species Pterocarpus erinaceus Poir.
}

\author{
Benziwa Nathalie Johnson ${ }^{1}$ (D) | Marie Luce Akossiwoa Quashie ${ }^{1}$ | Gilles Chaix ${ }^{2,3}$ | \\ Letizia Camus-Kulandaivelu $^{2,3}$ | Kossi Adjonou ${ }^{1}$ | Kossi Novinyo Segla ${ }^{1}$ | Adzo \\ Dzifa Kokutse $^{1}$ | Christine Ouinsavi ${ }^{4}$ | Babou André Bationo ${ }^{5}$ | \\ Habou Rabiou $^{6}$ | Kouami Kokou ${ }^{1}$ | Hélène Vignes ${ }^{2,3}$
}

\footnotetext{
${ }^{1}$ Laboratoire de Recherche Forestière (LRF), Université de Lomé, Lomé, Togo

${ }^{2}$ CIRAD, UMR AGAP, Montpellier, France

${ }^{3}$ AGAP, Univ Montpellier, CIRAD, INRAe, Institut Agro, Montpellier, France

${ }^{4}$ Laboratoire d'Etudes et de Recherches Forestières, Faculté d'Agronomie, Université de Parakou, Parakou, Bénin

${ }^{5}$ Institut de l'environnement et de recherches agricoles (INERA), Burkina Faso

${ }^{6}$ Faculté des Sciences Agronomiques (FSA), Université de Diffa, Diffa, Niger
}

\section{Correspondence}

Benziwa Nathalie Johnson, Laboratoire de Recherche Forestière (LRF), Université de Lomé, 01BP 1515, Lomé, Togo.

Email: benziwa.johnson@gmail.com

Funding InformationThis research was financially supported by Sud Expert Plantes Développement Durable (SEP2D) program [AAP1-45], Agence Universitaire de la Francophonie (AUF) [DRAO-1448-201902], Programme d'Appui à la Lutte contre le Changement Climatique: PALCC -AMCC+ [DCI-ENV/2016/39289 Devis programme multi-annuel nDCI-ENV-2017/387-416], Service de Coopération et d'Action Culturelle (SCAC) and Campus France, CIRAD for the "Actions Incitatives-Soutien aux doctorants" Program, and genotyping platform of Agap unit managed by Pierre Mournet.

\begin{abstract}
To study the genetic diversity and structure of the forest species Pterocarpus erinaceus Poir., seventeen polymorphic nuclear microsatellite markers were isolated and characterized, using next-generation sequencing. Three hundred and sixty-five (365) individuals were analyzed within fifteen (15) West African populations. The number of alleles for these loci varied from 4 to 30 , and the heterozygosity varied from 0.23 to 0.82 . The seventeen (17) primers designed here will allow characterizing the genetic diversity of this threaten species on its natural stands and to better understand the population differentiation mechanisms shaping it.
\end{abstract}

\section{KEYWORDS}

African tree species, genetic diversity, next-generation sequencing (NGS), nuclear microsatellites, Pterocarpus erinaceus 


\section{1 | INTRODUCTION}

Pterocarpus erinaceus Poir. (Lamarck \& Poiret, 1823) is commonly known as African rosewood. This important tree belonging to the Fabaceae family is native from the Guinean forest-savannah mosaic ecoregion and has been reported from Senegal to Cameroon (Adjonou et al., 2019; Arbonnier, 2004; Giffard, 1974). Stands of this Leguminous species are especially targeted for timber and wood fuelwood production, but this species has also several medicinal uses (Fontodji et al., 2011; Kokou et al., 2009; Segla et al., 2015). Recent scientific investigations on $P$. erinaceus international trade have highlighted a considerable increase in export volume of its wood from West Africa countries for Asia, particularly China (Dumenu, 2019; Lawson, 2015). As a consequence of its overexploitation, the Convention on International Trade in Endangered Species of Wild Fauna and Flora classified the species as threatened (CITES, 2016) and it has become the focus of conservation concern in African countries. Because of its high-quality wood, but also as a drought and fire-resistant plant species with traditional medicine uses in sub Saharan Africa (Duvall, 2008; Karou et al., 2003; Ouedraogo et al., 2012), P. erinaceus is a good model species for the study of genetic diversity in Pterocarpus genus.

Understanding the dynamics of P. erinaceus populations' evolution in West Africa in order to establish appropriate and efficient production and conservation strategies requires the study of its genetic diversity and structure on its natural stands. Among various molecular tools used to assess plant genetic diversity, microsatellite simple sequence repeats (SSR) markers are the most widely employed because they are codominant and possess high levels of polymorphism and stability (De et al., 2017; Morgante \& Olivieri, 1993).

So far, only few studies have addressed the question of genetic diversity and population structure with the Pterocarpus pantropical genus. Muller et al. (2006) have developed a set of eight (8) microsatellite markers for Pterocarpus officinalis Jacq., an important tree species of the Caribbean wetland forest. More recently, in order to facilitate population identification and biodiversity protection, Hong et al. (2020) have sequenced and analyzed the whole chloroplast genomes of five Pterocarpus species: $P$. macrocarpus, $P$. santalinus, $P$. indicus, $P$. pedatus, and P. marsupium. This study has also led to the description of chloroplastic SSR. The present study describes a new SSR set designed for $P$. erinaceus and its use to describe the genetic diversity of three hundred and sixty-five (365) individual trees originating from West Africa. Owing to the laborious and expensive microsatellites development by conventional methods (Oliveira et al., 2006; Pimentel et al., 2018), we chose to use next-generation sequencing (NGS) technologies. The major advantage of this approach is the identification of a large number of SSR allowed by the production an important volume of sequence data (Rico et al., 2013; Senan et al., 2014; Vieira et al., 2016).

\section{MATERIAL AND METHODS}

We sampled nine to thirty adult trees in 15 populations (Table 1) with a total of 365 trees in four countries of West Africa which are Benin, Burkina Faso, Niger, and Togo (Figure 1).

Freshly collected leaves were dried in a coffee filter containing $10 \mathrm{~g}$ Silica gel. Each filter containing sample was put in a plastic zip bag for transport to the laboratory. Our genomic library was constructed using DNA of $P$. erinaceus samples from twelve randomly

selected individuals among populations (Table 1).

\section{1 | DNA extraction}

Total genomic DNA extraction was performed with a solution of alkyltrimethylammonium bromide (MATAB) using twenty milligrams of dried leaves from each tree sample. Extraction protocol used derived from Bousquet et al. (1990) methodology.

The quality of the genomic extracted DNA was controlled on a $1 \%$ agarose gel, and quantification was done by Hoechst assay using fluoroskan (Fluoroskan ${ }^{\text {TM }}$ Microplate Fluorometer).

\section{2 | Cross-amplification test of $P$. officinalis microsatellites markers on $P$. erinaceus}

Cross-amplification tests using the SSR developed by Muller et al. (2006) on P. officinalis were performed using $P$. erinaceus individuals from different sampling sites except for Tamou reserve (Niger). Loci were amplified by PCR in a 96-well plate using $10-\mu \mathrm{L}$ volume reaction containing $20 \mathrm{ng}$ of DNA, $1 \mathrm{X}$ reaction buffer $\mathrm{B}$ $\left(\mathrm{Mg}^{2+}\right.$ free; $0.8 \mathrm{M}$ Tris- $\mathrm{HCl}, 0.2 \mathrm{M}\left(\mathrm{NH}_{4}\right)_{2} \mathrm{SO}_{4}, 0.2 \% \mathrm{w} / \mathrm{v}$ Tween20; Solis BioDyne), $0.08 \mu \mathrm{M}$ of the M13-labeled primer, $0.1 \mu \mathrm{M}$ of each primer forward fluorescent (FAM, NED, PET, and VIC) and the primer reverse, $0.1 \mu \mathrm{M}$ of $\mathrm{M} 13$ fluorescent primer, $2 \mathrm{mM}$ of $\mathrm{MgCl}_{2}$, $200 \mu$ M dNTPs, 0.4X Q-solution (Facilitates amplification of GC-rich templates; Qiagen ${ }^{\circledR}$ ), $0.04 \mathrm{mg} / \mathrm{ml}$ of BSA solution (Bovine Serum Albumine; Qiagen ${ }^{\circledR}$ ), and $0.06 \mathrm{U} / \mu \mathrm{L}$ of Taq DNA polymerase. PCR running conditions were as follows: initial denaturation at $94^{\circ} \mathrm{C}$ for $4 \mathrm{~min}$ followed by $36 \mathrm{cycles}$ each at $92^{\circ} \mathrm{C}$ in $30 \mathrm{~s}, 1 \mathrm{~min}$ at $52^{\circ} \mathrm{C}$, $45 \mathrm{~s}$ at $72^{\circ} \mathrm{C}$, and with a final extension step at $72^{\circ} \mathrm{C}$ for $5 \mathrm{~min}$. Electropherograms were analyzed, and allele sizes were determined using GeneMapper ${ }^{\circledR}$ software version 4.1 using GeneScan 600 $\mathrm{LIZ}$ as a size standard (Applied Biosystems). Four out of the eight primers failed to amplify the target loci (mPoCIRE01, mPoCIRE04, $\mathrm{mPoCIRH02}$, and mPoCIRE09), and two showed little polymorphism

(Table 2).

These eight loci were considered noninformative and showed insufficient variability to be used for genetic studies of $P$. erinaceus. 
FIGURE 1 Map of study area and location of sampling sites in the four West Africa countries. Burkina Faso: SA, Sarya; TI, Tiogo. Togo: OK, Oti-Kéran; FM, Fazao-Malfakassa; AB, Abdoulaye; AK, Plateau Akposso; TO, Togodo. Benin: KA, Koussoukpa; AD, Adakplamè; HO, Houin; BA, Bassila; PE, Pénessoulou; WA, Bénin Parc W. Niger: NI, Niger Parc W; NN, Tamou

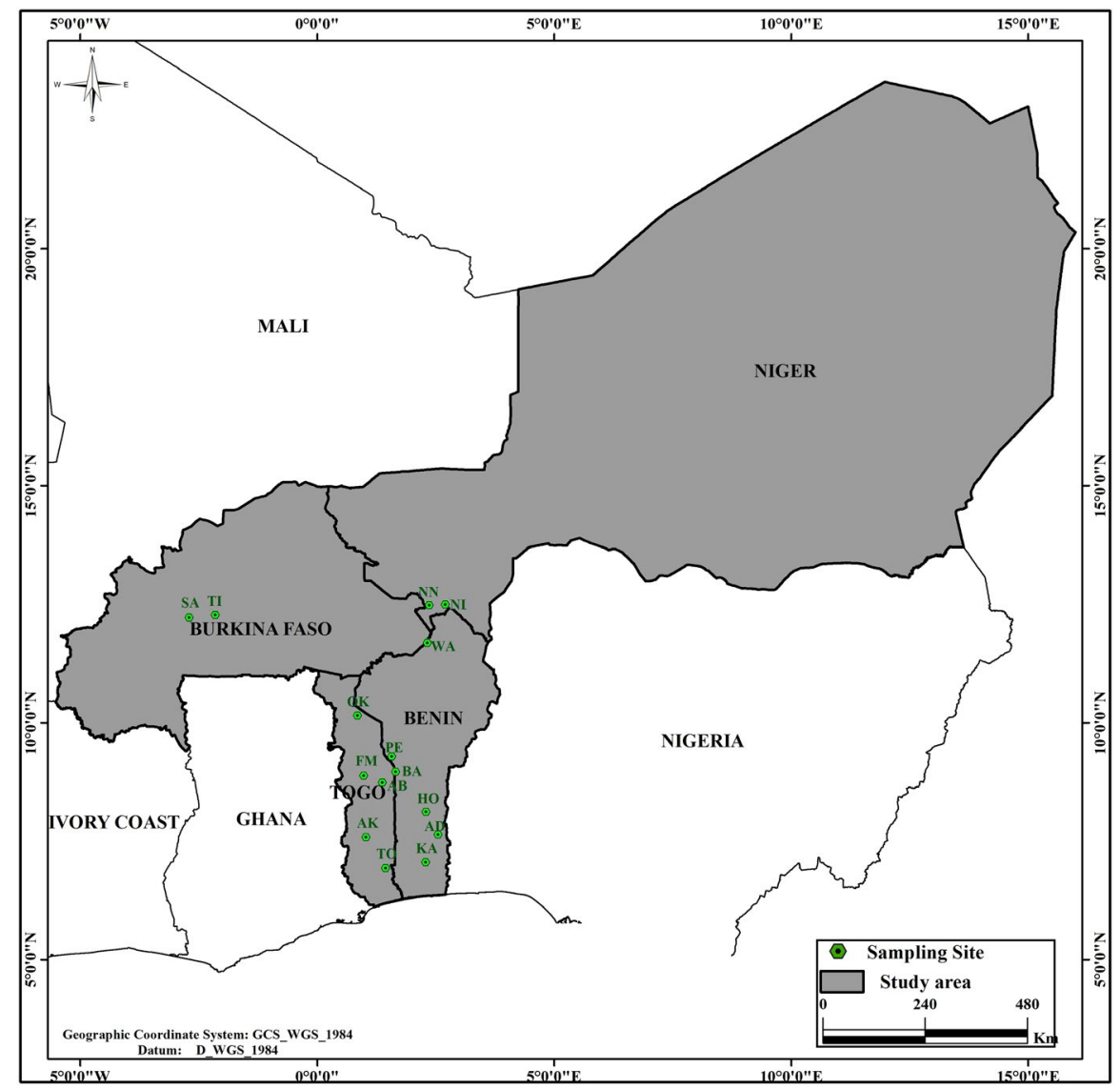

\subsection{Construction of the DNA library and validation}

The Westburg NGS DNA Library PrepKit was used to prepare the DNA library with a pooled DNA extract from twelve samples. The library was built following the manufacturer instructions. Using this kit, enzymatic fragmentation allows for obtaining DNA fragment sizes from 200 to $600 \mathrm{bp}$ (suggested by the manufacturer) depending on the reaction time and the amount of DNA input. DNA was fragmented in an Eppendorf Mastercycler ${ }^{\circledR}$ nexus using $35 \mu \mathrm{l}$ volume of pooled DNA (1 $\mu \mathrm{g})$ to which $5 \mu \mathrm{l}$ of ER/A-tailing buffer (10X) and $10 \mu \mathrm{l}$ of ER/A-tailing enzyme mix (5X) were added. The fragmentation program used in the thermocycler included a first step of precooling at $4^{\circ} \mathrm{C}$ for $5 \mathrm{~min}$ followed by the second step of fragmentation with three fragmentation times, $1 \mathrm{~min}$ at $4^{\circ} \mathrm{C}, 10 \mathrm{~min}$ at $32^{\circ} \mathrm{C}$, and $30 \mathrm{~min}$ at $65^{\circ} \mathrm{C}$.

The sample was then ligated with Illumina adapters. The recommended Illumina indexes in addition to the Westburg kit come from the following reference: TruSeq RNA Single Indexes Set A 12 Indexes (ref 20,020,492). Ligation reaction was performed in a PCR tube containing $45 \mu \mathrm{l}$ of fragmented DNA to which was added successively $20 \mu \mathrm{l}$ of ligation buffer (5X), $10 \mu \mathrm{l}$ of DNA ligase, $10 \mu \mathrm{l}$ of water, and $2.5 \mu$ l of DNA illumina adapter. Incubation of the ligation reaction was performed at $20^{\circ} \mathrm{C}$ for $15 \mathrm{~min}$.

Purification on magnetic beads (Agencourt AMPure XP beads -A63881-, Beckman Coulter) was performed before and after PCR. The amplification conditions included initial denaturation at $98^{\circ} \mathrm{C}$ for
$2 \mathrm{~min}$, followed by 7 cycles of $98^{\circ} \mathrm{C}$ for $20 \mathrm{~s}$, annealing at $60^{\circ} \mathrm{C}$ for $35 \mathrm{~s}$, elongation at $72^{\circ} \mathrm{C}$ for $30 \mathrm{~s}$, and a final $1 \mathrm{~min}$ elongation step at $72^{\circ} \mathrm{C}$.

The quality of DNA library was controlled using an Agilent 4,200 TapeStation with a screen tape D5000, and the fragments sized between 100 and 600 pb mainly, with an average of $260 \mathrm{bp}$. The DNA library (fragments) was quantified using the Takara kit $(638,324)$ on a qPCR machine (LightCycler ${ }^{\circledR} 480$ Real-Time PCR System, Roche Life Science).

\section{4 | Sequencing}

MiSeq system Illumina sequencer DNA was used to perform DNA sequencing on the genotyping platform at CIRAD-Montpellier. A 500 cycles NANO V2 cartridge Illumina ( $2 \times 250 \mathrm{pb})$ was used to sequence the library.

\section{5 | Design and choice of primers}

A total of 800,000 reads were generated for $P$. erinaceus DNA library. Development of optimized and streamlined microsatellites was based on a bioinformatics Galaxy pipeline and with following tools: FASTQ Groomer tool, Filter FASTQ tool, and ABySS parallel assembler (Simpson et al., 2009). The MISA MIcroSAtellite identification 


\begin{tabular}{|c|c|c|c|c|}
\hline Country & Sampling sites & $\begin{array}{l}\text { Number of trees } \\
\text { sampled }\end{array}$ & GPS & \\
\hline \multirow[t]{2}{*}{ Niger } & Parc W (NI) ** & 27 & $12^{\circ} 14^{\prime} 31.8^{\prime \prime} \mathrm{N}$ & $2^{\circ} 17^{\prime} 33.4^{\prime \prime} \mathrm{E}$ \\
\hline & Tamou (NN) ${ }^{* *}$ & 14 & $12^{\circ} 35^{\prime} 55.1^{\prime \prime} \mathrm{N}$ & $2^{\circ} 20^{\prime} 34.3^{\prime \prime} \mathrm{E}$ \\
\hline \multirow[t]{6}{*}{ Bénin } & $\begin{array}{l}\text { Koussoukpa } \\
(\mathrm{KA})^{*}\end{array}$ & 25 & $7^{\circ} 03^{\prime} 27.8^{\prime \prime} \mathrm{N}$ & $2^{\circ} 17^{\prime} 02.1^{\prime \prime}$ \\
\hline & Bassila (BA) * & 24 & $8^{\circ} 57^{\prime} 58.8^{\prime \prime} \mathrm{N}$ & $1^{\circ} 39^{\prime} 01.9^{\prime \prime} \mathrm{E}$ \\
\hline & $\begin{array}{l}\text { Pénessoulou } \\
(\mathrm{PE})^{* *}\end{array}$ & 27 & $9^{\circ} 18^{\prime} 01.7^{\prime \prime} \mathrm{N}$ & $1^{\circ} 23^{\prime} 40.1^{\prime \prime} \mathrm{E}$ \\
\hline & Parc W (WA) & 24 & $7^{\circ} 38^{\prime} 33.8^{\prime \prime} \mathrm{N}$ & $2^{\circ} 19^{\prime} 22.0^{\prime \prime} \mathrm{E}$ \\
\hline & $\underset{* *}{\text { Adakplamè (AD) }}$ & 27 & $7^{\circ} 38^{\prime} 33.8^{\prime \prime} \mathrm{N}$ & $2^{\circ} 33^{\prime} 02.3^{\prime \prime} \mathrm{E}$ \\
\hline & Houin $(\mathrm{HO})^{*}$ & 24 & $8^{\circ} 07^{\prime} 34.5^{\prime \prime} \mathrm{N}$ & $2^{\circ} 17^{\prime} 39.0^{\prime \prime} \mathrm{E}$ \\
\hline \multirow[t]{5}{*}{ Togo } & $\underset{* *}{\text { Oti-Kéran (OK) }}$ & 25 & $10^{\circ} 06^{\prime} 12.2^{\prime \prime} \mathrm{N}$ & $0^{\circ} 41^{\prime} 32.5^{\prime \prime} \mathrm{E}$ \\
\hline & $\begin{array}{l}\text { Fazao- } \\
\text { Malfakassa } \\
\left(\text { FM) }{ }^{*}\right.\end{array}$ & 30 & $8^{\circ} 30^{\prime} 31.7^{\prime \prime}$ & $0^{\circ} 51^{\prime} 56.3^{\prime \prime} \mathrm{E}$ \\
\hline & $\begin{array}{l}\text { Abdoulaye (AB) } \\
* *\end{array}$ & 30 & $8^{\circ} 40^{\prime} 30.2^{\prime \prime} \mathrm{N}$ & $1^{\circ} 21^{\prime} 02.2^{\prime \prime} \mathrm{E}$ \\
\hline & $\begin{array}{l}\text { Plateau Akposso } \\
\text { (AK) }\end{array}$ & 23 & $7^{\circ} 35^{\prime} 27.6^{\prime \prime} \mathrm{N}$ & $1^{\circ} 01^{\prime} 29.9^{\prime \prime} \mathrm{E}$ \\
\hline & Togodo (TO) * & 30 & $6^{\circ} 51^{\prime} 38.6^{\prime \prime} \mathrm{N}$ & $1^{\circ} 30^{\prime} 45.4^{\prime \prime} \mathrm{E}$ \\
\hline \multirow[t]{2}{*}{ Burkina Faso } & Sarya (SA) ** & 9 & $12^{\circ} 15^{\prime} 57^{\prime \prime} \mathrm{N}$ & $2^{\circ} 08^{\prime} 47^{\prime \prime} \mathrm{E}$ \\
\hline & Tiogo $(\mathrm{TI})^{* *}$ & 25 & $12^{\circ} 17^{\prime} 22^{\prime \prime} \mathrm{N}$ & $2^{\circ} 47^{\prime} 12^{\prime \prime} \mathrm{E}$ \\
\hline Total & & 365 & & \\
\hline
\end{tabular}

TABLE 1 Characteristics of sampled sites for Pterocarpus erinaceus: country location, name of sampling sites, number of trees sampled per site, and GPS coordinates

*and ${ }^{* *}$ geographic origin of individuals selected for genomic library construction.

${ }^{* *}$ geographic origin of individuals selected for the first screening.

tool (Thiel, 2003) and primer modeling software Primer3 (Whitehead Institute) were used for the identification and design of microsatellites primers in the generated draft assembly. A data matrix containing all the microsatellite primers was obtained as output.

Among the 38,715 single sequence repeats identified, primers were designed for 11,718 sequence repeats of which 3,530 were dinucleotide repeats, 2,970 trinucleotide repeats, 2,847 tetranucleotide repeats, 1,001 pentanucleotide repeats, 525 hexanucleotide repeats, and 844 contained complex SSR motifs.

Thirty microsatellites were identified and selected for initial screening on the basis of the type and size of the repeat motif, as well as the annealing temperature as previously described Muller et al. (2006). Therefore, dinucleotide and trinucleotide SSRs with a repeat motif of 15 to $30 \mathrm{bp}$ were randomly selected from those generated. The selected primers amplified SSR motifs with a minimum of five repetitions. The annealing temperature varied from 54 to $56^{\circ} \mathrm{C}$, including that used by Muller et al. (2006) for P. officinalis $\left(54^{\circ} \mathrm{C}\right)$. This first test was performed on an $\mathrm{ABI} 3500 \mathrm{XL}$ sequencer (Life technologies) using genomic DNA extract from eight individuals selected from different countries (Table 1).

An M13 tailed primer (5'-CACGACGTTGTAAAACGAC-3'), allowing detection of fluorescence, was added to the forward primers. Each PCR amplification was performed in a 96-well plate using $10-\mu \mathrm{L}$ volume reaction containing $20 \mathrm{ng}$ of DNA, 1X reaction buffer $\mathrm{B}\left(\mathrm{Mg}^{2+}\right.$ free; $0.8 \mathrm{M}$ Tris- $\mathrm{HCl}, 0.2 \mathrm{M}\left(\mathrm{NH}_{4}\right)_{2} \mathrm{SO}_{4}, 0.2 \% \mathrm{w} / \mathrm{v}$ Tween20; Solis BioDyne), $0.08 \mu \mathrm{M}$ of the M13-labeled primer, $0.1 \mu \mathrm{M}$ of each primer forward fluorescent (FAM, NED, PET, and VIC) and the primer reverse, $0.1 \mu \mathrm{M}$ of $\mathrm{M} 13$ fluorescent primer, $2 \mathrm{mM}$ of $\mathrm{MgCl}_{2}$, $200 \mu \mathrm{M}$ dNTPs, 0.4X Solution "S" (additive solution that facilitates amplification of difficult templates; Solis BioDyne), and $0.05 \mathrm{U} / \mu \mathrm{L}$ of Taq DNA polymerase. PCR running conditions were as follows: initial denaturation at $94^{\circ} \mathrm{C}$ for 4 min followed by 36 cycles each at $92^{\circ} \mathrm{C}$ in $30 \mathrm{~s}, 1 \mathrm{~min}$ at $52^{\circ} \mathrm{C}, 45 \mathrm{~s}$ at $72^{\circ} \mathrm{C}$, and with a final extension step at $72^{\circ} \mathrm{C}$ for $5 \mathrm{~min}$.

The analysis of electrophoregrams with GeneMapper ${ }^{\circledR}$ software version 4.1 using GeneScan $600 \mathrm{LIZ}$ as a size standard (Applied Biosystems) allowed determining allele sizes. Among the 30 primer pairs tested, 17 were selected. Indeed, we eliminated primers with profiles that were difficult to read on GeneMapper ${ }^{\circledR}$, or with no or little polymorphism. The 17 selected primers are shown in Table 4 and were used for screening the remaining individuals in order to calculate genetic parameters.

Genetic parameters including alleles' number per locus, number of private alleles, observed heterozygosity $(\mathrm{Ho})$, and expected heterozygosity $(\mathrm{He})$ were computed using GenAIEx software version 6.0 (Peakall \& Smouse, 2012). Deviation from the Hardy-Weinberg 




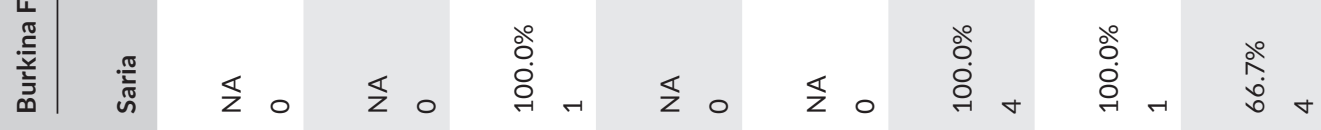

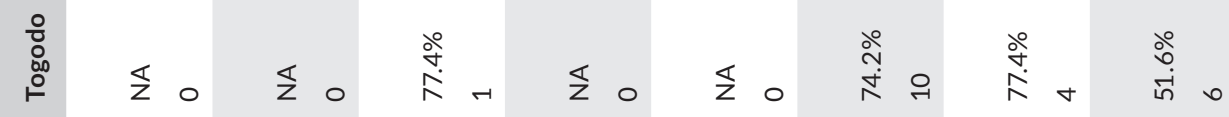

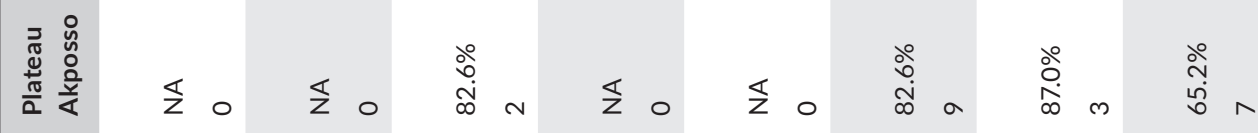

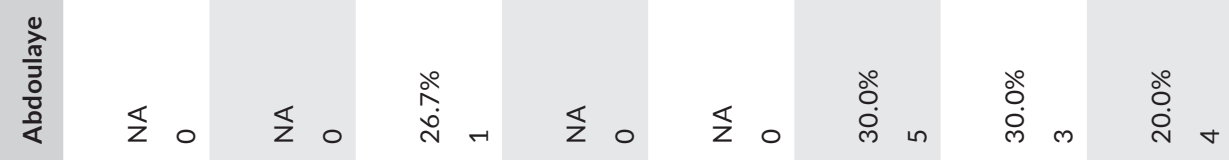

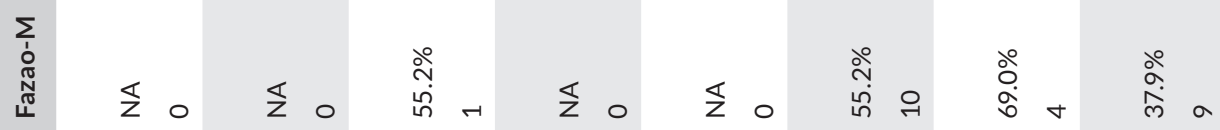

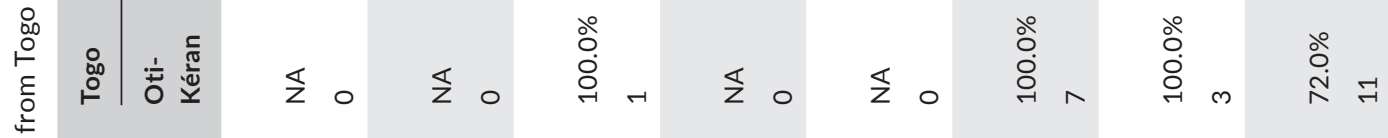

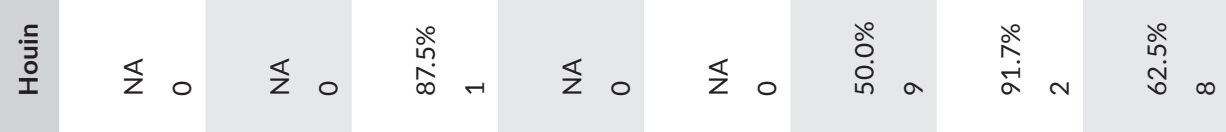

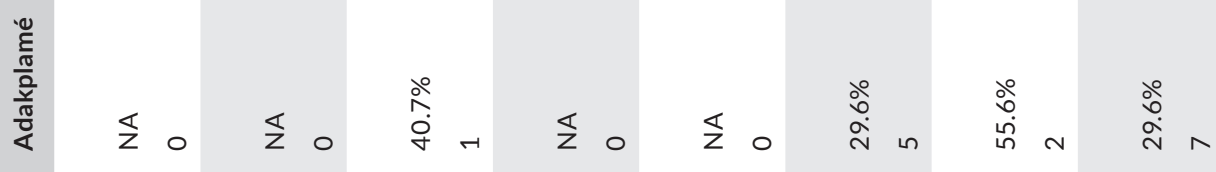

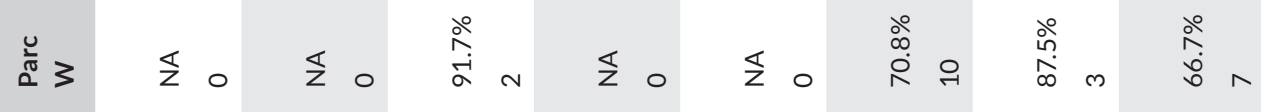

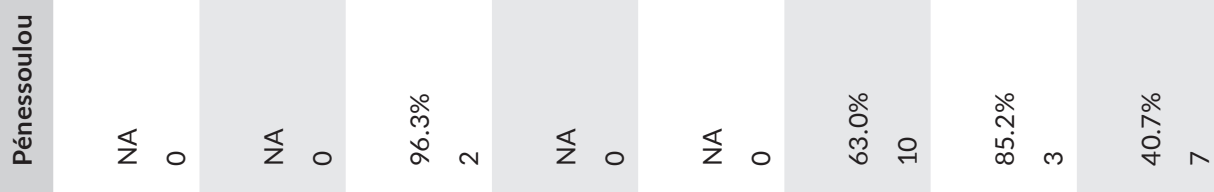

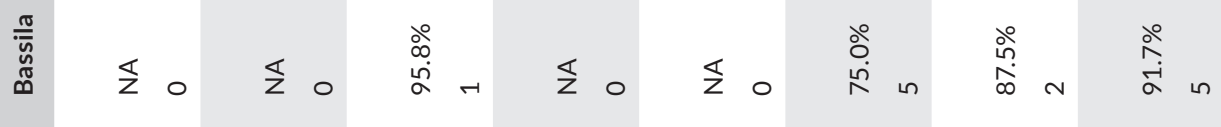
产高

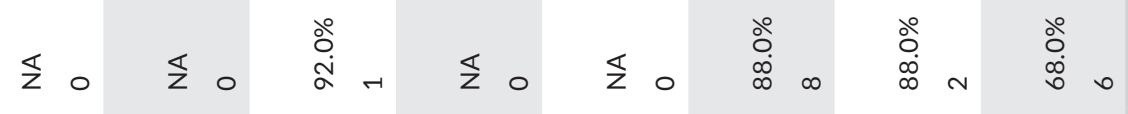

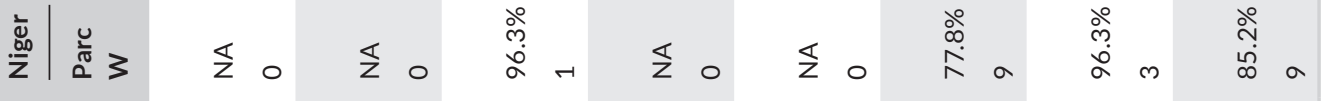




equilibrium (HWE) was measured for each locus by chi-squared tests and $p$-value significance assessed in the context of multiple testing with a Bonferroni correction procedure (Rice, 1989). Significant linkage disequilibrium was rated among these loci by using GENETIX software version 4.05 (Belkhir et al., 1996). MICRO-CHECKER software version 2.2.3 (Van Oosterhout et al., 2004) was used to check for the null alleles in microsatellite data.

\section{3 | RESULTS AND DISCUSSION}

Contrary to Hong et al. (2020) results in chloroplast genomes of five Pterocarpus species, among the single sequence repeats identified there was no single-nucleotide repeats motifs accounted. The observed proportion of dinucleotide, trinucleotide, and tetranucleotide were respectively $30.1 \%, 25.3 \%$, and $24.3 \%$, while the tetranucleotide proportion was $2.27 \%$. $4.5 \%$ of nucleotides were hexanucleotide repeats, and $7.2 \%$ were complex SSR motifs.

A total of 237 alleles were identified for the 17 locus on the 365 characterized trees, with each locus having from 4 to 30 alleles (mean of 13.9 alleles per locus) (Table 4). Table 3 shows the total numbers of specific alleles for each population (private alleles) across all 17 loci. A total of 34 private alleles have been identified out of the 15 populations. Their distribution varied from 0 allele (BA, AB, SA populations) to 13 alleles (OK population). The majority of them (22/34 alleles) was characterized by an allelic frequency smaller than $5 \%$. The 12 remaining private alleles have a frequency varying from $5 \%$ to $12 \%$. Mean values for the expected heterozygosity $(\mathrm{He})$ varied from 0.42 to $0.65(0.57 \pm 0.02)$ and from 0.41 to $0.65(0.55 \pm 0.02)$ for observed heterozygosity
(Ho) for the population screened (Table 3). Evidence of significant linkage disequilibrium was found for 12 out of 136 possible SSR pairwise combinations after Bonferroni corrections. Significant departures from Hardy-Weinberg equilibrium for 14 out of 17 loci were recorded after Bonferroni corrections, and presence of null alleles was suggested for all loci excepted for mPeCIR_D2 and mPeCIR_T3.

Two populations of Togo, Oti-Kéran and Fazao-Malfakassa, and the population of Pénélessou in Benin have a particularly high rate of private alleles scoring respectively to $11.5 \%, 5.6 \%$, and $5.1 \%$. On the other hand, the populations of Abdoulaye (Togo), Bassila (Bénin), and Sarya (Burkina Faso) have no private allele. Observed heterozygosity generally follows the trend of private alleles level with high values for Oti-Kéran (0.55), FazaoMalfakassa (0.65), and Pénélessou (0.63) compared to Abdoulaye (0.41) and Bassila (0.50) (Table 3). From a conservation perspective and on the basis of genetic diversity level, Oti-Kéran, FazaoMalfakassa, and Pénélessou are the most interesting populations sampled in this study. These three populations notably come from protected sites (reserves and parks) located in the Sudanian area. On the contrary, Abdoulaye's samples come from the community forest exploited by the surrounding local populations following the principles of integrated and participatory management. The type forest management undergone by the tree populations may not be however the only explanative factor of the observed diversity levels. Studied populations all belong to natural stands distributed according to the climatic gradient of the Sahelian, Sudanian, and Guinean zones and exhibit high morphological variation. Johnson et al. (2020) identified 3 morphotypes for P. erinaceus in Togo characterized by phenotypic specificity related to

TABLE 3 Private alleles and heterozygosity levels across populations

\begin{tabular}{|c|c|c|c|c|c|c|}
\hline Country & Sampling sites & $\begin{array}{l}\text { Total number } \\
\text { of alleles }\end{array}$ & $\begin{array}{l}\text { Number of } \\
\text { private alleles }\end{array}$ & $\begin{array}{l}\text { Percentage of } \\
\text { private alleles }\end{array}$ & $\begin{array}{l}\text { Observed } \\
\text { heterozygosity (Ho) }\end{array}$ & $\begin{array}{l}\text { Expected heterozygosity } \\
\text { (He) }\end{array}$ \\
\hline \multirow[t]{2}{*}{ Niger } & Parc W (NI) & 100 & 2 & $2 \%$ & $0.58 \pm 0.22$ & $0.61 \pm 0.19$ \\
\hline & Tamou (NN) & 79 & 3 & $3.7 \%$ & $0.56 \pm 0.24$ & $0.57 \pm 0.18$ \\
\hline \multirow[t]{6}{*}{ Bénin } & Koussoukpa (KA) & 85 & 3 & $3.5 \%$ & $0.52 \pm 0.33$ & $0.52 \pm 0.29$ \\
\hline & Bassila (BA) & 77 & 0 & $0 \%$ & $0.50 \pm 0.28$ & $0.48 \pm 0.25$ \\
\hline & Pénessoulou (PE) & 123 & 7 & $5.6 \%$ & $0.63 \pm 0.23$ & $0.65 \pm 0.22$ \\
\hline & Parc W (WA) & 96 & 2 & $2.1 \%$ & $0.56 \pm 0.22$ & $0.62 \pm 0.21$ \\
\hline & Adakplamè (AD) & 83 & 1 & $1.2 \%$ & $0.50 \pm 0.29$ & $0.52 \pm 0.27$ \\
\hline & Houin $(\mathrm{HO})$ & 86 & 2 & $2.3 \%$ & $0.49 \pm 0.29$ & $0.54 \pm 0.28$ \\
\hline \multirow[t]{5}{*}{ Togo } & Oti-Kéran (OK) & 113 & 13 & $11.5 \%$ & $0.55 \pm 0.28$ & $0.65 \pm 0.26$ \\
\hline & $\begin{array}{l}\text { Fazao-Malfakassa } \\
\text { (FM) }\end{array}$ & 116 & 6 & $5.1 \%$ & $0.65 \pm 0.23$ & $0.64 \pm 0.23$ \\
\hline & Abdoulaye (AB) & 43 & 0 & $0 \%$ & $0.41 \pm 0.38$ & $0.42 \pm 0.23$ \\
\hline & $\begin{array}{l}\text { Plateau Akposso } \\
\text { (AK) }\end{array}$ & 89 & 1 & $1.1 \%$ & $0.56 \pm 0.26$ & $0.57 \pm 0.23$ \\
\hline & Togodo (TO) & 91 & 3 & $3.2 \%$ & $0.52 \pm 0.30$ & $0.53 \pm 0.28$ \\
\hline \multirow[t]{2}{*}{ Burkina Faso } & Sarya (SA) & 78 & 0 & $0 \%$ & $0.58 \pm 0.26$ & $0.62 \pm 0.20$ \\
\hline & Tiogo (TI) & 75 & 3 & $4 \%$ & $0.61 \pm 0.20$ & $0.60 \pm 0.16$ \\
\hline
\end{tabular}


TAB LE 4 Characteristics of 17 microsatellite primers designed for Pterocarpus erinaceus Poir

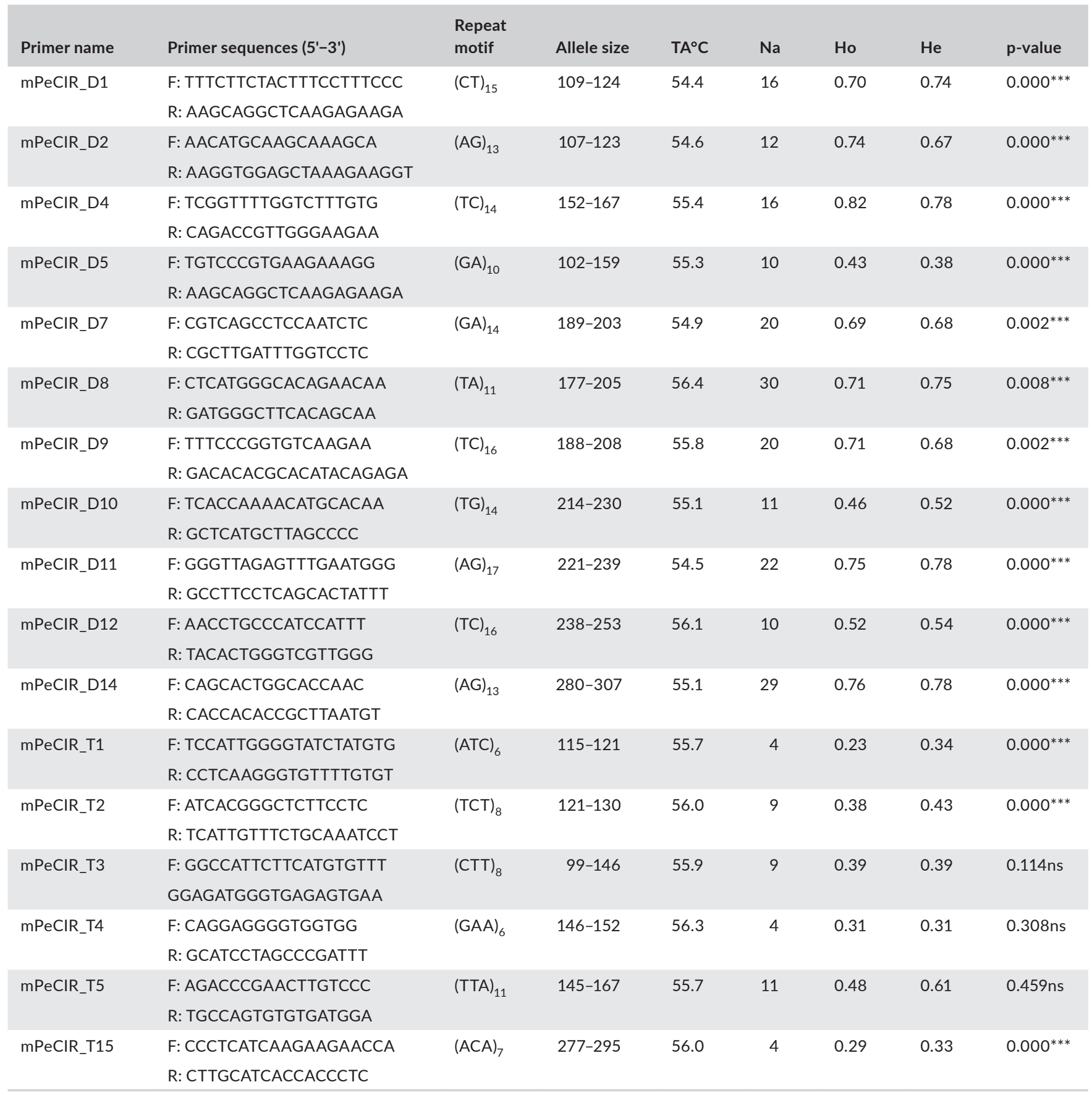

Note: $\mathrm{He}$, expected heterozygosity under Hardy-Weinberg equilibrium; Ho, observed heterozygosity; $\mathrm{Na}$, number of individuals; $\mathrm{TA}^{\circ} \mathrm{C}$, annealing temperature. $p$-values for the Hardy-Weinberg Equilibrium test, significance threshold adjusted using sequential Bonferroni correction.

${ }^{*} p \leq .05,{ }^{* * *} p \leq .001, \mathrm{~ns}=$ not significant.

a climate gradient. On the basis of descriptors related to leaves, fruits, and seeds, a morphotype adapted to the dry Sudanian zone was described in Oti-Kéran and Fazao-Malfakassa sites, a morphotype adapted to the semiwet Sudano-Guinean zone was described in Abdoulaye site, and a third morphotype adapted to the wet Guinean zone was described in Akposso and Togodo sites. From this point of view, the level of genetic diversity could also be related to ecotypes but further work is requested to investigate this hypothesis. Finally, we would advise to account both for genetic diversity level and for ecotype specificity in future conservation programs for $P$. erinaceus.

This set of 17 specific primers of $P$. erinaceus would serve to study the genetic diversity of this species in West Africa. While the SSR set developed by Muller et al. (2006) on P. officinalis does not show a proper amplification and/ or polymorphism level on $P$. erinaceus, the transferability of the SSR markers set presented in this study on other Pterocarpus species should be further investigated. 


\section{4 | CONCLUSION}

In this study, thirty (30) microsatellites primers were developed based on $P$. erinaceus populations from three different African countries by using NGS (Illumina MiSeq sequencing technology). Seventeen (17) of these nuclear markers showed a high level of polymorphism in fifteen (15) locations, thus providing the first set of microsatellite markers for $P$. erinaceus. These microsatellite markers will be useful for characterizing genetic diversity and analyzing genetic structure for $P$. erinaceus populations in order to contribute to the implementation of optimal management and conservation plans for this species.

\section{ACKNOWLEDGMENTS}

We are grateful to Prof. Christine OUINSAVI head of the Forest Studies and Research Laboratory from the University of Parakou in Bénin, Prof Ali MAHAMANE and Dr Habou RABIOU from the University of Diffa in Niger, Dr Babou André BATIONO from Burkina Faso, and their laboratory teams and collaborators for providing plant material from these countries.

\section{CONFLICTS OF INTEREST}

The authors have no conflicts of interest to declare.

\section{AUTHOR CONTRIBUTION}

Benziwa Nathalie Johnson: Conceptualization (equal); Data curation (equal); Formal analysis (equal); Funding acquisition (equal); Investigation (equal); Methodology (equal); Project administration (equal); Resources (equal); Visualization (equal); Writing-original draft (lead); Writing-review \& editing (equal). Marie Luce Akossiwoa Quashie: Conceptualization (equal); Funding acquisition (equal); Investigation (supporting); Methodology (equal); Project administration (lead); Supervision (equal); Visualization (equal); Writingoriginal draft (supporting); Writing-review \& editing (equal). Gilles Chaix: Conceptualization (equal); Formal analysis (equal); Funding acquisition (equal); Investigation (supporting); Methodology (equal); Project administration (equal); Resources (equal); Supervision (equal); Validation (equal); Visualization (equal); Writing-review \& editing (equal). Letizia Camus-Kulandaivelu: Formal analysis (equal); Validation (equal); Visualization (equal); Writing-review \& editing (equal). Kossi Adjonou: Conceptualization (supporting); Funding acquisition (equal); Investigation (supporting); Visualization (supporting); Writing-review \& editing (equal). Kossi Novinyo Segla: Conceptualization (supporting); Investigation (equal); Visualization (supporting); Writing-review \& editing (equal). Adzo Dzifa Kokutse: Conceptualization (equal); Funding acquisition (equal); Visualization (equal); Writing-review \& editing (equal). Christine Ouinsavi: Resources (equal); Writing-review \& editing (supporting). Babou André Bationo: Resources (equal); Writing-review \& editing (supporting). Habou Rabiou: Resources (equal); Writing-review \& editing (supporting). Kouami Kokou: Conceptualization (equal); Funding acquisition (equal); Visualization (equal); Writing-review \& editing (equal). Hélène Vignes: Data curation (equal); Formal analysis (equal); Investigation (equal); Methodology (equal); Resources (equal); Visualization (equal); Writing-review \& editing (equal).

\section{DATA ACCESSIBILITY}

The data have been deposited with links to BioProject accession number PRJNA604893 in the NCBI BioProject database (https:// www.ncbi.nlm.nih.gov/bioproject/). 17 Primers designed and evaluated: end of text (Table 4).

\section{ORCID}

Benziwa Nathalie Johnson (iD https://orcid. org/0000-0003-0018-8085

\section{REFERENCES}

Adjonou, K., Houetchegnon, T., Rabiou, H., Kossi, S. N., Abotsi, E. K., Johnson, B. N., Alaba, P., Ouinsavi, C. A. N., Quashie, A. M. L., \& Kokutse, A. D. (2019). Challenges of conservation and sustainable management of African rosewood (Pterocarpus erinaceus) in West Africa. Natural Resources Management and Biological Sciences, (Intech Open), 29, https://doi.org/10.5772/intechopen.88796

Arbonnier, M. (2004). Arbres, arbustes et lianes des zones sèches d'Afrique de l'Ouest (Éditions CIRAD, Margraf Publishers GMBH, MNHN). 579 p.

Belkhir, K., Borsa, P., Chikhi, L., Raufaste, N., \& Bonhomme, F. (1996) GENETIX 4.05, logiciel sous Windows TM pour la génétique des populations. Retrieved from http://www.Genetix.univ-montp2.fr/genet ix/genetix.htm

Bousquet, J., Simon, L., \& Lalonde, M. (1990). DNA amplification from vegetative and sexual tissues of trees using polymerase chain reaction. Canadian Journal of Forest Research, 20, 254-257. https://doi. org/10.1139/x90-037

CITES. (2016). Convention sur le commerce international des espèces de faune et de flore sauvages menacées d'extinction. Dix-septième session de la Conférence des Parties Johannesburg (Afrique du Sud).

De, J., Zhu, W., Liu, T., Wang, Z., \& Zhong, Y. (2017). Development of microsatellite markers using Illumina MiSeq sequencing to characterize Ephedra gerardiana (Ephedraceae) 1. Applications in Plant Sciences, 5, 4. https://doi.org/10.3732/apps.1600104

Dumenu, W. K. (2019). Assessing the impact of felling/export ban and CITES designation on exploitation of African rosewood (Pterocarpus erinaceus). Biological Conservation, 236, 124-133. https://doi. org/10.1016/j.biocon.2019.05.044

Duvall, C. S. (2008). Pterocarpus erinaceus Poir. [Internet] Record from PROTA4U. In D. Louppe, A. A. Oteng-Amoako, \& M. Brink (Eds.), PROTA (Plant Resources of Tropical Africa/Ressources végétales de I'Afrique tropicale) (pp 478-482).

Fontodji, J. K., Atsri, H., Adjonou, K., Radji, A. R., Kokutse, A. D., Nuto, Y., $\&$ Kokou, K. (2011). Impact of charcoal production on biodiversity in Togo (West Africa). In Togo (West Africa), The Importance of Biological Interactions in the Study of Biodiversity, Jordi Lopez Pujol, IntechOpen, (pp. 215-230). https://doi.org/10.5772/22969. Available from: https://www.intechopen.com/books/the-importance-of-biological -interactions-in-the-study-ofbiodiversity/impact-of-charcoal-produ ction-on-biodiversity-in-togo-west-africa-

Giffard, P. L. (1974). L'Arbre dans le paysage sénégalais: sylviculture en zone tropicale sèche. Dakar : GERDAT--Centre technique forestier tropical. $452 \mathrm{p}$.

Hong, Z., Wu, Z., Zhao, K., Yang, Z., Zhang, N., Guo, J., Tembrock, L. R., \& Xu, D. (2020). Comparative analyses of five complete chloroplast genomes from the genus Pterocarpus (Fabacaeae). International Journal of Molecular Sciences, 21, 3758, 18 p. 
Johnson, B. N., Quashie, M. L. A., Adjonou, K., Segla, K. N., Kokutse, A. D., \& Kokou, K. (2020). Morphological variability of pterocarpus erinaceus poir. in Togo. International Journal of Forestry Research, 2020, $16 \mathrm{p}$.

Karou, D., Dicko, M. H., Sanon, S., Simpore, J., \& Traore, A. S. (2003). Antimalarial activity of Sida acuta Burm. f. (Malvaceae) and Pterocarpus erinaceus Poir. (Fabaceae). Journal of Ethnopharmacology, 89, 291-294. https://doi.org/10.1016/j.jep.2003.09.010

Kokou, K., Nuto, Y., \& Honan, A. (2009). Impact of charcoal production on woody plant species in West Africa: A case study in Togo. Scientific Research and Essays, 4, 881-893.

Lamarck, J. B. A. P., \& Poiret, J. L. M. (1823). Tableau encyclopédique et méthodique des trois règnes de la nature. Botanique. : Panckoucke.

Lawson, S. (2015). The illegal rosewood boom in West Africa; How Chinese demand is driving conflict, corruption and human rights abuses. Presentation to Chatham House Illegal Logging Stakeholder Update Meeting, 25th June 2015.

Morgante, M., \& Olivieri, A. M. (1993). PCR-amplified microsatellites as markers in plant genetics. The Plant Journal, 3, 175-182. https://doi. org/10.1046/j.1365-313X.1993.t01-9-00999.x

Muller, F., Vaillant, A., Bâ, A., \& Bouvet, J.-M. (2006). Isolation and characterization of microsatellite markers in Pterocarpus officinalis Jacq. Molecular Ecology Resources, 6, 462-464.

Oliveira, E. J., Pádua, J. G., Zucchi, M. I., Vencovsky, R., \& Vieira, M. L. C. (2006). Origin, evolution and genome distribution of microsatellites. Genetics and Molecular Biology, 29, 294-307. https://doi. org/10.1590/S1415-47572006000200018

Ouedraogo, N., Sawadogo, W., Tibiri, A., Bayet, C., Lompo, L., Hay, E. A., Koudou, J., Dijoux, M.-G., \& Guissoux, P. I. (2012). Pharmacological properties and related constituents of stem bark of Pterocarpus erinaceus Poir. (Fabaceae). Asian Pacific Journal of Tropical Medicine, 5, 46-51.

Peakall, R., \& Smouse, P. E. (2012). GenAIEx 6.5: Genetic analysis in Excel. Population genetic software for teaching and research-an update. Bioinformatics, 28, 2537-2539. https://doi.org/10.1093/bioin formatics/bts460

Pimentel, J. S. M., Carmo, A. O., Rosse, I. C., Martins, A. P. V., Ludwig, S., Facchin, S., Pereira, A. H., Brandão-Dias, P. F. P., Abreu, N. L., \& Kalapothakis, E. (2018). High-throughput sequencing strategy for microsatellite genotyping using Neotropical fish as a model. Frontiers in Genetics, 9, 8. https://doi.org/10.3389/fgene.2018.00073

Rice, W. R. (1989). Analyzing tables of statistical tests. Evolution, 43, 223225. https://doi.org/10.1111/j.1558-5646.1989.tb04220.x

Rico, C., Normandeau, E., Dion-Côté, A.-M., Rico, M. I., Côté, G., \& Bernatchez, L. (2013). Combining next-generation sequencing and online databases for microsatellite development in non-model organisms. Scientific Reports, 3(1), https://doi.org/10.1038/srep03376

Segla, K. N., Adjonou, K., Radji, A. R., Kokutse, A. D., Kokou, K., Rabiou, H., Kamana, P., Bationo, B. A., \& Ali, M. (2015). Importance socio-économique de Pterocarpus erinaceus Poir. au Togo. European Scientific Journal, ESJ, 11(23), 199-217.

Senan, S., Kizhakayil, D., Sasikumar, B., \& Sheeja, T. E. (2014). Methods for development of microsatellite markers: An overview. Notulae Scientia Biologicae, 6, 1-13. https://doi.org/10.15835/nsb619199

Simpson, J. T., Wong, K., Jackman, S. D., Schein, J. E., Jones, S. J., \& Birol, I. (2009). ABySS: A parallel assembler for short read sequence data. Genome Research, 19, 1117-1123. https://doi.org/10.1101/ gr.089532.108

Thiel, T. (2003). MISA-Microsatellite identification tool. Retrieved from http://Pgrc.Ipk-Gatersleben.de/Misa/ [Accessed 17 June 2019].

Van Oosterhout, C., Hutchinson, W. F., Wills, D. P., \& Shipley, P. (2004). MICRO-CHECKER: Software for identifying and correcting genotyping errors in microsatellite data. Molecular Ecology Notes, 4(3), 535538. https://doi.org/10.1111/j.1471-8286.2004.00684.x

Vieira, M. L. C., Santini, L., Diniz, A. L., \& de Munhoz, C. F. (2016). Microsatellite markers: What they mean and why they are so useful. Genetics and Molecular Biology, 39, 312-328. https://doi. org/10.1590/1678-4685-GMB-2016-0027

How to cite this article: Johnson BN, Quashie MLA, Chaix G, et al. Isolation and characterization of microsatellite markers for the threatened African endemic tree species Pterocarpus erinaceus Poir. Ecol Evol. 2020;10:13403-13411. https://doi. org/10.1002/ece3.6944 